\title{
The Missing Link Between the Fraction Concept and Its Representation
}

\author{
D A Oktafiana ${ }^{1}$, H E L Tobing ${ }^{2}$, Y Mariani $^{3}$, E Marlinda $^{4}$, Ismaini $^{5}$, L \\ Asri $^{6}$, Darmawijoyo $^{7, *}$, and Somakim ${ }^{8}$
}

${ }^{1}$ Mathematics Education Department, Sriwijaya University
${ }^{2}$ Mathematics Education Department, Sriwijaya University
${ }^{3}$ Mathematics Education Department, Sriwijaya University
${ }^{4}$ Mathematics Education Department, Sriwijaya University
${ }^{5}$ Mathematics Education Department, Sriwijaya University
${ }^{6}$ Mathematics Education Department, Sriwijaya University
${ }_{7}^{7}$ Mathematics Education Department, Sriwijaya University
${ }^{8}$ Mathematics Education Department, Sriwijaya University
${ }^{*}$ Corresponding author. Email: darmawijoyo@ unsri.ac.id

\section{ABSTRACT}

This paper was to describe primary and junior high school students' perceptions of the fraction concept through their representations. The subject of this research was the $5^{\text {th }}$ grade and $7^{\text {th }}$-grade students. This research revealed that students who studied varying images could be used to construct the concept of fractions. In contrast, using a single image could lead to a misconception of the fraction.

\section{Keywords: Fraction Concept, Representation.}

\section{INTRODUCTION}

A fraction is one of the complex materials that have to be learned by students during the elementary school period [1][2][3]. In mathematics teaching and learning, the fraction has been regarded as one of the most problematic elementary schools' mathematics concepts. The fraction is taught to grade 3 to 5 students of elementary school. The conceptual comprehension of fractions in the previous grades is a prerequisite for learning fractions in grade 6 of elementary school, and hopefully, a misconception about it can be avoided. The students' difficulty in comprehending the concept of fraction results from its abstractness so that a real situation needs to be created to make it meaningful to them [4]. According to Piaget, students aged 7 to 11 years old belong to the concrete operational stage, which means that their ideas are based on their observation of real objects, yet they have started to generalize by manipulating objects to acknowledge them.

Therefore, as candidates of a mathematics teacher, we are required to be able to convey the concept of fraction well, comprehend the way to convey it as attractive as possible through showing the concrete example and have a strong commitment to helping students in comprehending the concept more deeply [5]. It also reveals that learning fractions using concrete things can help students to acquire comprehension from their intuition informally to formal problem-solving.
Nevertheless, the teacher should pay attention to the media used in the learning process to avoid students' misconceptions about the material. Moreover, [6] the use of inappropriate learning methods and strategy also contributes to students' misconceptions. It cannot be denied that objects in mathematics are abstract, so that representation to learn and comprehend abstract ideas is necessary.

There are so many discussions that state that the use of mathematical representation can develop mathematical concept comprehension due to the abstractness of mathematics, such as in [7] [8] [9] [10] [11] [12] [13] [14]. Thus representation is very important as a substitute for those abstract ideas and a means of comprehension. The term representation here refers to the external and internal imaging of mathematical phenomena, enabling teachers to manage, document, communicate, and interpret mathematical ideas. It can be expressed in different forms, including experience-based script, namely real-life contexts, objects that can be manipulated, such as image or diagram, verbal interchange, and written symbols [15][16].

One of the representations is a visual representation, which is [17] a non-symbolic representation that does not contain numbers and is considered more intuitive. Foresman [18] introduced early age students to the initial concept of the fraction informally through visual representation, such as "cake" or "circle" representation. By introducing mathematical concepts using visual representation, students can avoid confusion, which 
frequently appears when they learn symbolic number theory. Thus, using visual representation is likely to help students develop it into a mathematical symbolism [19]. The finding [20] also shows that visual skills correlate significantly with the students' ability to comprehend mathematics. It is in line with [21] [22] that visual representation enables students to show conceptual comprehension over fraction and relation between numerator and denominator. Besides, visual representation even enable students to show comprehension towards basic fraction arithmetic [23]. Thus, the visual representation might play an important role in fraction conceptual comprehension.

However, many students have not been able to use the visual model when solving the problem, or the model they made does not represent a mathematical situation. Students need guidance and help from teachers and more knowledgeable fellow students when selecting, interpreting, and creating mathematical visual media [24] [25]. Thus, students need teachers' help in creating visual media to help them comprehend fractions. Not only students, but many researchers have also reported a lack of teacher competence in using representation to support student learning [26] [27] [28]. Likewise, as we will be discussing below, the subjects of this study themselves told that teachers in the classroom only copied the visual form on the book onto the blackboard. It means that teachers in elementary schools still lack competence in selecting certain representation modes, such as manipulation or model.

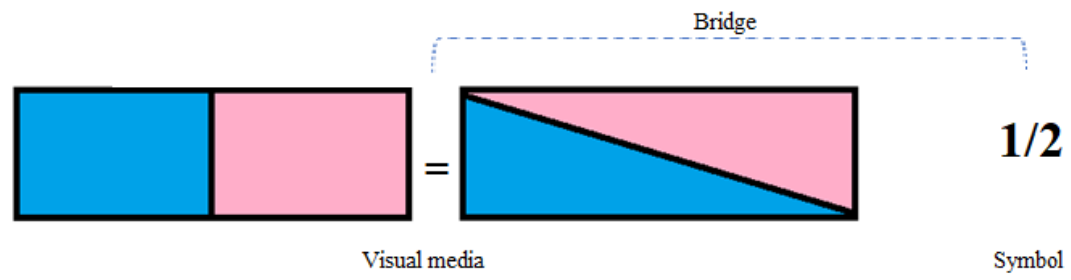

Figure 1. Bridging the gap between visual image and the symbolic

Therefore, through this research, students are expected to understand the concept of a fraction more deeply and familiarize students with exploring their knowledge in other activities. The activities carried out aim to build a deep understanding of the fraction concept by introducing a broader model and providing access to several alternative representations. Instruction should be able to bridge the gap from the more meaningful and grounded strategy of the use of models to the more abstract and efficient algorithms in order to maintain high retention. It is in line with [29] that the quality of learning tends to be maximal when students are faced with a variety of different situations, which are represented through different manifestations or forms. With the same conceptual structure presented in different forms of perception, students can help collect the essence of mathematics from an abstraction [7].

\section{METHOD}

This type of research is descriptive research. Descriptive research intends to understand behavior, perception, motivation, action holistically and employing description in the form of words and language, in a specific natural context, and by using various natural methods [30].

The subject of this research was the $7^{\text {th }}$ grade $(\mathrm{X})$ and $5^{\text {th }}$-grade students $(\mathrm{Y})$. The object of this research was the fraction in terms of representation and symbol through visual media.
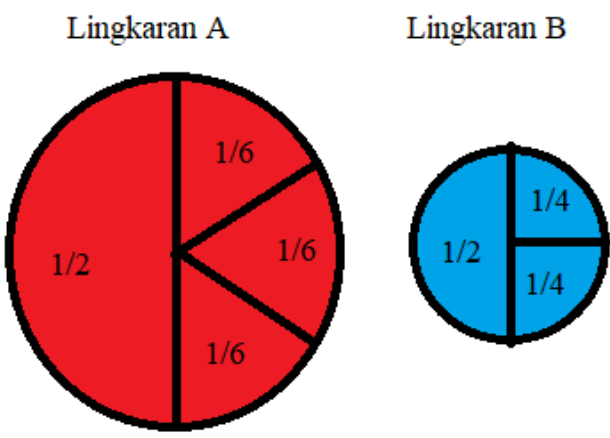

Lingkaran C

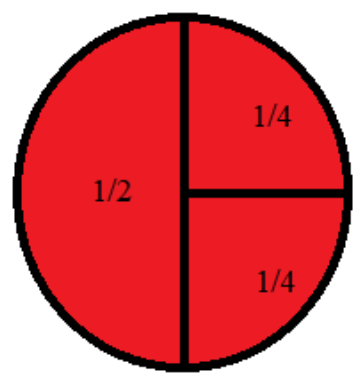

Figure 2. Two circles of the same size and one different size 

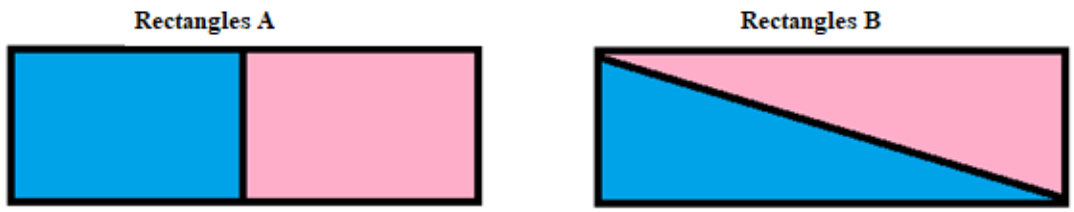

Figure 3. Two Rectangles (1/2) with different cuts

The research data collection technique is conducted through interviews and documentation using video. The form of the statement at the time of the interview is as follows:

\subsection{Opening}

1. Have you studied fractions? And do you understand what a fraction is?

2. Does the teacher use teaching aids, and if so, what are the teaching aids?

3. Why are they called $1 / 2,1 / 4$, and $1 / 6$ ?

\subsection{Students' perceptions of fractions in} activity 1 (comparison of circle $A$ and circle

B)

- Which is greater, $1 / 6$, or $1 / 4$ ? What is the reason?

2.3. Students' perceptions of the two large circles (comparison of circle $A$ and circle $C$ )

- Which is greater than $1 / 6$ or $1 / 4$ ? What is the reason?

\subsection{Students' perceptions towards the} fraction $1 / 2$ in activity 2 (picture 2 )

1 . How much is the value of the pieces that are not numbered? What is the reason?

2. Do the picture pieces have the same value to one another? What is the reason?

\section{FINDING AND DISCUSSION}

\subsection{Finding}

At the implementation stage, $\mathrm{X}$ and $\mathrm{Y}$ have been informed about what to do when shooting the video recording. At the beginning of the activity, the researcher conducted a question and answered the research subject's session. The first question whether $\mathrm{x}$ and $\mathrm{y}$ had learned about fractions? And what teaching aids have been used by the teacher to teach the fractions material?, while giving a little description that in the first picture (Activity 1), two circles were consisting of large and small circles. In the large circle, there are four parts, namely $1 / 6,1 / 6$, $1 / 6$, and $1 / 2$, and in the small circle, there are three parts, namely $1 / 4,1 / 4$, and $1 / 2$.
The researcher asks which of the pictures or pieces is the larger $1 / 6$ or $1 / 4$, then $\mathrm{x}$ and $\mathrm{y}$ think before giving a response or answer. After finishing with the first picture, in session one, the researcher also showed two circles that were equal to $1 / 4$ and $1 / 6$ pieces by repeating the questions at the beginning of the activity (Activity 1). The researcher shows the second image (Activity 2), where the researcher asks $\mathrm{x}$ and $\mathrm{y}$ to see what images of the existing fields. For Figure $\mathrm{B}$, a question is asked what the value of the fraction of its parts is and agrees that the size is $1 / 2$ of each piece, then $\mathrm{x}$ and $\mathrm{y}$ are asked to pay attention to Figure $\mathrm{B}$ and what is the value of the size of each part, then asked whether the pieces are from Figure $\mathrm{A}$ and Figure $\mathrm{B}$.

The researcher initiated the activity by giving several questions to the subject. The following was the transcript of the researcher interview with Subject X:

$\mathrm{P} \quad$ : Have you ever learned fractions?

$\mathrm{X}:$ : Yes

$\mathrm{P} \quad$ : When studying fractions, did the teacher use teaching aids?

$\mathrm{X}: \mathrm{No}$

$\mathrm{P} \quad$ : So how do the teachers teach?

$\mathrm{X}$ : Directly write on the blackboard, immediately draw on the board.

From the interview, it can be seen that $\mathrm{X}$ has learned fractions and also said that the teacher when explaining fractions, did not use teaching aids, but the teacher immediately drew a square/circle shape on the blackboard. After conducting the interview, the researcher entered the next stage, namely Limited vision on fraction form 1 different size. At this stage, the researcher uses props, as shown in Figure 1

In the activity regarding different sizes, $\mathrm{X}$ was given two circle images in the form of a large circle, and a small circle with parts of the circle cut into pieces. To see X's understanding, the researcher interviewed about the value of each chip and the reasons. The following is a transcript of the question and answer conducted by the researcher with $\mathrm{X}$ :

$\mathrm{P}$ : There are two forms. What form do you take?

$\mathrm{X}$ : circle

$\mathrm{P}$ : Where are the big circles and small circles? 
$\mathrm{X}$ : this is a large circle, and this is a small circle (while showing large and small circles)

$\mathrm{P}$ : If you take the $1 / 2$ piece of the small blue circle, how much is this worth?

$\mathrm{X}: 1 / 2$

Q : Why is it worth $1 / 2$ ?

$\mathrm{X}$ : because the circle is divided by 2

$\mathrm{P}$ : How much is this one? (while holding the bluechip which is worth $1 / 4$ )

$\mathrm{X}: 1 / 4$

Q : Why is it worth $1 / 4$ ?

$\mathrm{X}$ : because it is divided by 4

$\mathrm{P}$ : How much is this? (While the large red circle pieces are worth $1 / 6$ )

$\mathrm{X}: 1 / 6$

$\mathrm{P}:$ Why, $1 / 6$ ?

$\mathrm{X}$ : because it is divided by 6 .

Then the researcher asked $\mathrm{X}$ to compare the part of the small blue circle, which has a value of $1 / 4$, with the part of the large red circle, which is $1 / 6$

P: Now, if we compare the $1 / 4$ chip from the small circle with the 1/6 chip from the big circle, which one is bigger?

$\mathrm{X}: 1 / 4$ (hesitated)

$\mathrm{P}$ : (while pressing the question again), which part of keeping is bigger than the one?

$\mathrm{X}: 1 / 6$ (x changes the answer while looking back at the piece the researcher is holding)

$\mathrm{P}$ : Why?

$\mathrm{X}$ : because the size is bigger than the one.

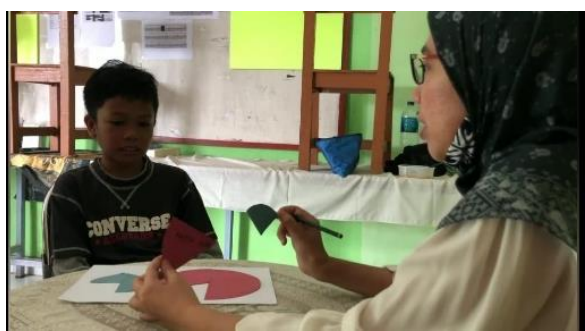

Figure 4. Activity 1 with a different size model on subject X

Then the researcher gave two large circles of the same size in red. In the first large circle, there are 1 $1 / 2$ pieces and two colored $1 / 4$ pieces forming the first large circle. There is a $1 / 2$ part in the second big circle, and three pieces $1 / 6$ part to form the second big circle.

$\mathrm{P}$ : If you take a 1/6 large circle with a $1 / 4$ chip in the big circle, which one is bigger?

$\mathrm{X}: 1 / 4$

$\mathrm{P}$ : Why, $1 / 4$ ?

$\mathrm{X}$ : because $1 / 4$ the size is bigger

Q : Can you write down the mathematical symbols? (additional question)

$\mathrm{X}$ : yes, I can.

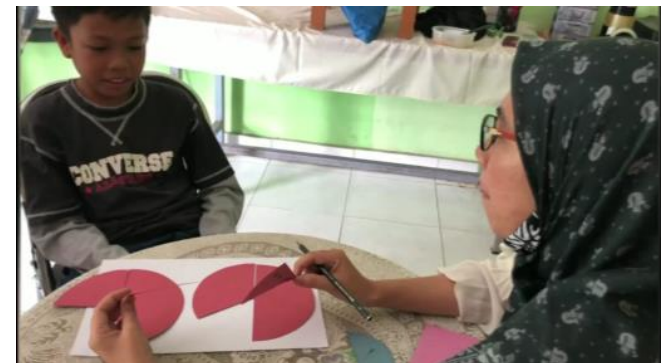

Figure 5. Activity with the same size model on subject X

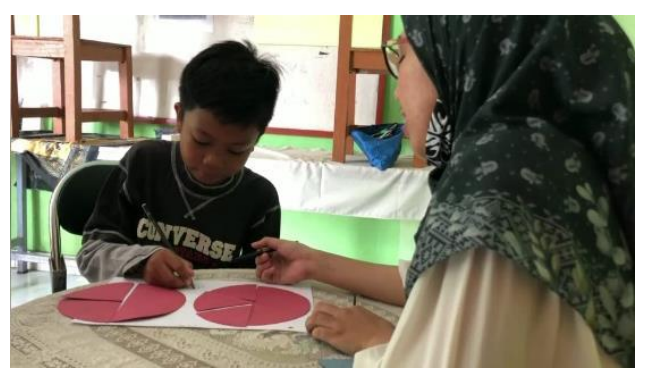

Figure 6. write down the mathematical symbols by subject $\mathrm{X}$

Subject 2 (Y) was also given the same questions as $\mathrm{X}$ at a different time and place. At the beginning of the activity, the researcher gave several questions about the subject. Here is the transcript of the researcher interview with Y:

$\mathrm{Q}$ : Has Oddie learned fractions yet?

$\mathrm{Y}:$ : Yes

$\mathrm{P}$ : What is a fraction?

Y : ehmm ... (looks confused and just smiles)

$\mathrm{P}$ : When studying fractions, did the teacher use teaching aids?

$\mathrm{Y}:$ No, only the pictures in the book

From the interview, it can be seen that $\mathrm{Y}$ has studied fractions and also understands fractions. $\mathrm{Y}$ also said that the teacher, when explaining fractions, did not use props.

\section{Activity 1 on Subject Y}

$\mathrm{P}$ : There are two forms. What form do you take? $\mathrm{Y}$ : circle

$\mathrm{P}$ : Which are the big circles and the small ones?

$\mathrm{Y}$ : this is a large circle, and this is a small circle (while showing large and small circles)

$\mathrm{P}$ : If you take the $1 / 2$ piece of the small blue circle, how much is this worth?

Y $: 1 / 2$

Q : Why is it worth $1 / 2$ ?

$\mathrm{Y}$ : because the size divides the two circles

$\mathrm{P}$ : How much is this one? (while holding the bluechip which is worth $1 / 4$ )

Y $: 1 / 4$

Q : Why is it worth $1 / 4$ ?

$\mathrm{Y}$ : because it divides 4 
$\mathrm{P} \quad$ : How much is this? ((While the big red circle that is worth $1 / 6)$

$\mathrm{Y}: 1 / 6$

$\mathrm{P} \quad$ : Why, $1 / 6$ ?

$\mathrm{Y} \quad$ : because it divides 6

$\mathrm{P}$ : Now, if we compare the $1 / 4$ chip from the small circle with the $1 / 6$ chip from the big circle, which one is bigger?

$\mathrm{Y}: 1 / 6$ (pointing to the piece from the big circle)

$\mathrm{Q}:$ Why is $1 / 6$ more?

$\mathrm{Y}$ : because it's in a big circle and the size is bigger than the one.

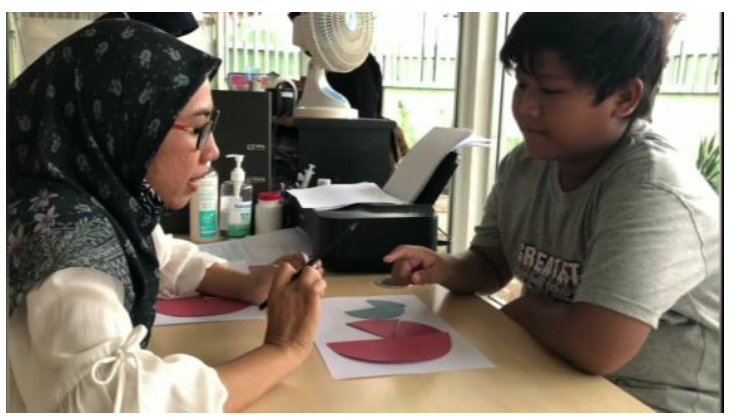

Figure 7. Activity 1 with a different size model on subject $\mathrm{Y}$

Then the researcher gave two large circles of the same size in red. In the first large circle, there are 1 $1 / 2$ pieces and two colored $1 / 4$ pieces forming the first large circle. There is a one-piece $1 / 2$ part in the second big circle and three pieces of $1 / 6$ to form the second big circle.

$\mathrm{P}$ : Now, if you take a 1/6 large circle with a $1 / 4$ of the big circle, which one is bigger?

$\mathrm{Y}: 1 / 4$

$\mathrm{P}$ : Why, $1 / 4$ ?

$\mathrm{Y}$ : because $1 / 4$, the size is bigger.

$\mathrm{P}$ : Okay, because it's bigger than the one.

So which one is bigger?

$\mathrm{Y}$ : this one (pointing at the $1 / 4 \mathrm{chip}$ ).

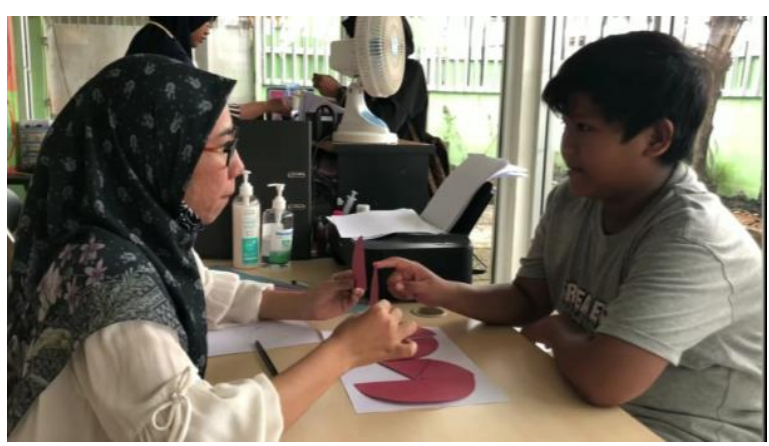

Figure 8. Activity with the same size model, show the biggest part by subject Y

Draw a rectangle divided by two vertically and diagonally. The following is a transcript of the researcher interview with subject $1(\mathrm{X})$ :
$\mathrm{P} \quad$ : Here, you have another picture; what shape is this?

$X$ : the shape of a rectangle, rectangle

$\mathrm{P}$ : Okay, when studying fractions, which form do you usually use?

$\mathrm{X}$ : this one (pointing to a vertically divided rectangle)

$\mathrm{P}$ : How much is this part of you? (designates the pieces in the given square)

$\mathrm{X}: 1 / 2$

$\mathrm{P}$ : Why, $1 / 2$ ?

$\mathrm{X}$ : because it is divided by 2

$\mathrm{P} \quad$ : How much is this part worth? (designates one of the pieces on the diagonally cut square)

$\mathrm{X}: 1$

$\mathrm{P} \quad$ : 1? right? (X looks confused, so the researcher asks follow-up questions)

$\mathrm{X}$ : yes

$\mathrm{P} \quad$ : Why 1 ?

$\mathrm{X}$ : Because it is divided by 2

$\mathrm{P}$ : Meaning?

$\mathrm{X}: 1 / 2$

$\mathrm{P}$ : So how much is this one?

$\mathrm{X}: 1 / 2$

$\mathrm{P}$ : Okay. Is the area of this chip and this chip the same?

(While holding two pieces cut in different ways) $X$ : It's the Same.

$\mathrm{P}$ : Why is it the same?

$\mathrm{X}$ : Because both are divided by 2
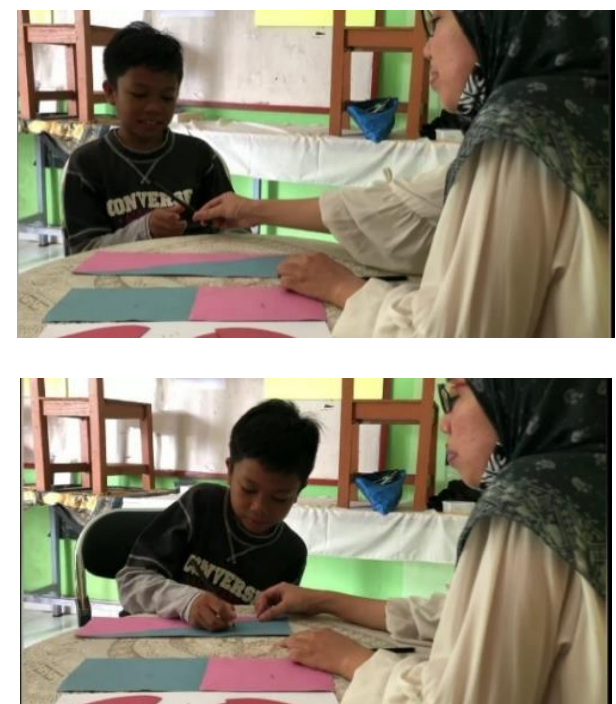

Figure 9. Activity 2 with a different shape model, $\mathrm{X}$ can write down the fraction symbol

Subject $\mathrm{Y}$ is also given a different form from the first. Researchers also asked several things. The following is a transcript of the researcher interview with subject $2(\mathrm{Y})$ :

$\mathrm{P}$ : There are other forms; what form is this?

Y : rectangle shape 
$\mathrm{P} \quad$ : If you cut this rectangle in half, how much is this worth?

(designates the chip in the assigned square)

Y $: 1 / 2$

$\mathrm{P}$ : Why, $1 / 2$ ?

$\mathrm{Y}:$ because the square is divided by 2

$\mathrm{P}$ : How much is this part worth? (designates one of the pieces on the diagonally cut square)

Y $: 1 / 2$

$\mathrm{P}$ : Why, 1/2?

$\mathrm{Y}$ : because it's divided by 2

$\mathrm{P}$ : Okay, now what happens if the area of this chip and this chip the same?

(While holding two pieces cut in different ways)

$\mathrm{Y} \quad$ : no

P : Why?

$\mathrm{Y}$ : because there are four corners and three corners

$\mathrm{P}$ : Which is bigger?

$\mathrm{Y}$ : the rectangular one (pointing to the vertically cut piece).
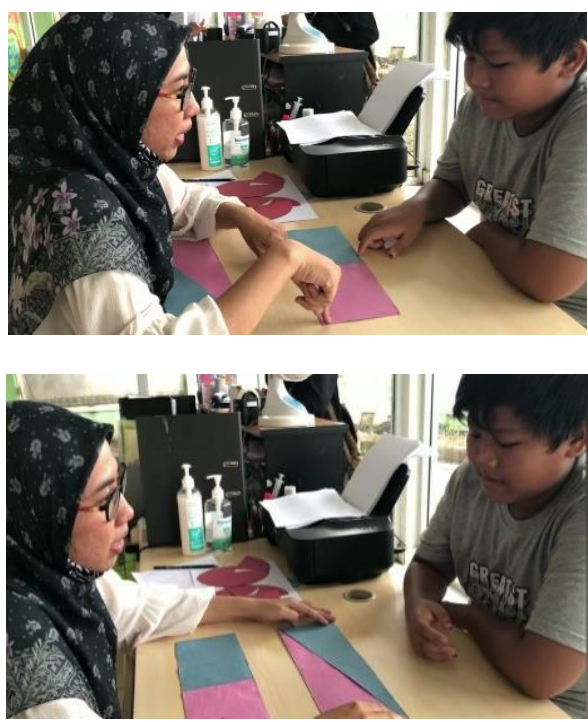

Figure 10. Activity 2 with a different shape model on subject $Y$

\subsection{Discussion}

\section{Activity 1}

Students' perceptions towards fractions in activity 1 , In comparing $1 / 4$ to $1 / 6$ pieces/parts, the first medium represented two fractions using a partiallywhole area model [31]. For activity 1, this model represented the concept of comparing fractions with different sizes (invariance). $\mathrm{X}$ and $\mathrm{Y}$ said that the $1 / 6$ slice was bigger than $1 / 4$ for the same reason they saw based on the media (see Figure 1). They see that circle $\mathrm{A}$ is bigger than circle $\mathrm{B}$, so they assume that $1 / 6>1 / 4$. It shows that $X$ at the beginning answered which is bigger because it is only cut into four parts, the researcher emphasizes which part is bigger, $\mathrm{X}$ again answers the 1/6 part because the slice is $1 / 6$ bigger. But Y immediately answered that the $1 / 6$ part was bigger because it was seen from the picture. Here it can be concluded that they can compare the fractions based on their slice or area. It contrasts with [32] that the fractions themselves do not explain anything about the actual size of the whole or the parts' actual size but only represent the relationship between the part and the whole. When $\mathrm{X}$ and $\mathrm{Y}$ studied fraction initially, teachers used the partwhole technique through a single image. The comparison method is less used than the partialwhole method [31]. When it was used more than one image in representing fractions, $\mathrm{X}$ and $\mathrm{Y}$ were not aware of symbol meaning. For example, when the researcher showed a 1/6-part of the big circle and a 1/4-part of the small circle to X and Y, they said the first one was bigger than the second one. Since a 1/6part of the big circle labeled by symbol $1 / 6$ and a 1/4part of the small circle labeled by symbol $1 / 4$, respectively, they said that $1 / 6$ was bigger than $1 / 4$. We might conclude that $\mathrm{X}$ and $\mathrm{Y}$ could not distinguish between a representation and its symbol. Bruner's theory [33] is that, at the enactive stage, a person learns about the world through direct responses or actions to an object. In the iconic stage (iconic), learning occurs through models and pictures and verbal visualization. In the symbolic stage, students are able to describe the capacity to think in abstract terms by manipulating symbols directly. Bruner's theory refers to the use of concrete objects in learning. So before students know the symbols or formulas to be used, they are first introduced to mathematical concepts using concrete objects; after students begin to understand the concepts, they are given an exercise problem using the description of the concrete objects earlier. $\mathrm{X}$ has been able to pass the iconic and symbolic stages.

\section{Activity 2}

The model in activity 2 represents the same division concept but not the overall invariance principle, where the media size is the same, but the sections are different. Students' perceptions of fractions in activity 2, X had seen the researcher's visual form, while $Y$ had never done it. The researcher asks $\mathrm{X}$ and $\mathrm{Y}$ what the fractions are in image $\mathrm{B}$, where the image is cut into two parts diagonally. $\mathrm{X}$ and $\mathrm{Y}$ answer correctly that the part is $1 / 2$ because it is cut into two equal parts. However, when researchers asked whether the pieces of the same color had the same area? They answered that they were not the same because the pieces were different.

From the activities that have been carried out, namely the problems regarding Different Size and Different Shape, it can be seen that the use of a limited area image context will cause students not to understand the concept of fractions well. It is in line with what was stated by [34] that students who were 
taught fractions with almost always related contexts to the same form would tend to have difficulty coping with fraction-related tasks in different situations. The area model approach was not successful enough to help students construct strong and flexible fraction concepts [35].

For fraction learning, student representations' solution serves as a teacher measure to identify understandings or misconceptions about concepts such as equal division, sub-units, or invariance of the whole; it is in line with opinion [36]. Besides, using effective representations can deepen students' understanding of fractions; using two different models and asking students to make connections between them can expand their concept of fractions [37]. Previous studies have reported that using the model effectively in fraction activities is very important [38] [39] [40]. Thus, when teachers plan pedagogical representations of fractions, they must examine and select the appropriate and useful representations. The teacher can use representation in learning fractions, namely, area, length, and set model, adjusted according to student abilities. Model an area (for example, circular pie slices, rectangular arrangement, geographic board, or dotted paper, pattern blocks, and the like.) by dividing the entire area into equal parts. This model is most often presented to students predominantly present in curriculum materials [41] and teacher textbooks [35]. In the early stages of teaching fractions, the area model is very effective because it explains the part-whole concept of fractions, and the size is relatively equal [42] [37]. However, students studying fractions for the first time may have difficulty dividing the circle model evenly because they have to consider the center angle of the circle [37], [43] revealing that students who have studied fractions with the pie/circle model show a lower ability to transfer skills to other manipulative slice shapes because the pie/circle structure has the same slice shape centered at the center of the circle thereby giving students no opportunity to interpret parts of its structure. A long model (for example, Cuisenaire bar, number line.), which compares measurements of a length over the area. Linear models, displaying a representation of the length given or displayed as a number line, thus enabling students to integrate their knowledge of fractions and integers in a continuous model [44] [45] [15]. Model sets (for example, twocolor counters, objects, other calculations, and the like.) The set model requires students to perceive a set of discrete objects (integers) as one unit, which can pose some challenges [46] because students tend to pay attention to set size (for example, there are 18 balls in a container) but not with the same number of sets in the whole (that is, three sets of the six balls). Much of the literature has presented mixed results and made suggestions about the effectiveness of this model set. As noted by the following researchers [47] [48] [49] [32] [15], recognize the importance of set models due to the application of students' prior knowledge of integer material and its relationship to the many real-world uses of fractions.

Emphasized that the quality of conceptual learning tends to be maximized when students are faced with a concept with a variety of different situations, which are represented through different manifestations or forms [29]. With the same conceptual structure presented in different forms of perception, children can be helped to collect the essence of mathematics from an abstraction [7]. If students wish to build a deep understanding of the concept of fractions, it is important to let them become acquainted with the broader model and provide access to several alternative forms of representation of fractions in addition to the broad model.

\section{CONCLUSION}

Activities 1 and 2 aim to investigate students' perceptions of the use of representations in mathematics teaching that they have acquired and their knowledge of pedagogical representations. The findings obtained by the researcher are 1. Students have never been given in variation model during classroom learning; 2 . that is, the most common models are area (especially a circle with cuts) and a long/linear model (using various rectangular stripe arrangements); 3. Students have already understood the concept of fractions when they are given the same visual form; 4

\section{REFERENCES}

[1] Mamede, Ema \& Oliveira, Issues on Children's Ideas of Fraction When Quotient Interpretation is Used, Proceedings of The Seventh Congress of The European Society for Research in Mathematics Education, vol 1, 2011, p 10

[2] Charalambous \& Pitta Pantazi, Drawing on a Theoretical Model To Study Students' Understandings of Fractions, Journal of Educational Studies in Mathematics, vol 64, 2007, pp 293-316.

[3] Kyriakides Andreas O, Questioning Assumptions That Limit The Learning of Fractions: The Story of Two Fifth Graders, Proceedings of The Seventh Congress of The European Society For Research in Mathematics Eduaction, vol 17, 2011, p 1075. 
[4] Kania N, Alat peraga untuk memahami konsep pecahan, Journal The Original Research of Mathematics, vol 2, 2018, pp 1-12.

[5] Suwarto, Konsep Operasi Bilangan Pecahan Melalui Garis Bilangan, Jurnal Pendidikan Matematika, vol 7, 2018, pp 327 - 336.

[6] Pertiwi Zulkardi \& Darmawijoto, Pembelajaran pecahan dengan menggunakan manik susunJurnal Review Pembelajaran Matematika, vol 2, 2017, pp 153 - 166.

[7] Clarke D M, Roche A, \& Mitchell A, 10 practical tips for making fractions come alive and make sense, Journal Mathematics Teaching in the Middle School, vol 13, 2008, pp $373-380$.

[8] Duval R, A cognitive analysis of problems of comprehension in the learning of mathematics, Journal Educational Studies in Mathematics vol 61, 2006, pp 103 - 131. DOI : $10.1007 / \mathrm{s} 10649-006-0400-\mathrm{z}$

[9] Greeno, J. G., \& Hall, R. P., Practicing representation: Learning with and about representational forms, Journal Phi Delta Kappan, vol 78, 1997, pp 361-367.

[11] McKendree J., Small C., \& Stenning K, The role of representation in teaching and learning critical thinking, Journal Educational Review, vol 54, 2002, pp 57 - 67. DOI : $10.1080 / 00131910120110884$.

[12] Woleck K. R., Listen to their pictures: An investigation of children's mathematical drawings The Roles of Representation in School Mathematics 2001 Yearbook, Ed. A A Cuoco and F R Curcio, Reston, VA: National Council of Teachers of Mathematics , 2001, pp 215-227.

[13] Zhang X., Clements M. A., \& Ellerton N. F., Conceptual mis(understandings) of fractions: From area models to multiple embodiments, Mathematics Education Research Journal, vol 27,2015 , pp 233 - 261. DOI : 10.1007/s13394014-0133-8

[14] NCTM, Principles to actions: Ensuring mathematical success for all, Reston, VA: Author, 2014.

[15] Lee M. Y. \& Ji-Eun Lee, Pre-service Teachers' Perceptions of the Use Representations and
Suggestions for Students' Incorrect Use, EURASIA Journal of Mathematics, Science and Technology Education, vol 15, 2018. DOI : 10.29333/ejmste/103055.

[16] Lesh R., Post T., \& Behr M., Representations and Translations among Representations in Mathematics Learning and Problem Solving Problems of Representations in the Teaching and Learning of Mathematics, Ed., C Janvier, Hillsdale, NJ: Lawrence Erlbaum, 1987, pp 3340 .

[17] Van den Heuvel \& Panhuizen M., The didactical use of models in realistic mathematics education: An example from a longitudinal trajectory on percentage, Journal Educational Studies in Mathematic, vol 54, pp $9 \quad-\quad 15 . \quad$ DOI 10.1023/B:EDUC.0000005212.03219.dc.

[18] Opfer J E \& Siegler R S, Development of quantitative thinking, Ed., K Holyoak and R Morrison, UK: Oxford University Press, 2012, pp 585-605.

[19] Scott Foresman \& Addison Wesley, Mathematics, Sanford, NC, U.S.A : Diamond Edition, 2011.

[20] Van Garderen D., Spatial visualization, visual imagery, and mathematical problem solving of students with varying abilities, Journal of Learning Disabilities, vol 39, 2006, pp 496 506. DOI : $10.1177 / 00222194060390060201$

[21] Empson S. B., Equal sharing and shared meaning: The development of fraction concepts in a first grade classroom, Journal of Cognition and Instruction, vol 17, 1999, pp 283 -342. DOI : 10.1207/S1532690XCI1703_3.

[22] Sophian C., Garyantes D., \& Chang C., When three is less than two: Early developments in children's understanding of fractional quantities, Developmental Psychology vol 33, 1997, pp 731 - 744. - DOI : 10.1037//00121649.33.5.731.

[23] Levine S. C., Huttenlocher J., Taylor A., \& Langrock A., Early sex differences in spatial skill, Developmental Psychology, vol 35, 1999, pp 940 - 949. DOI : 10.1037/00121649.35.4.940.

[24] Abrams J. P., "Teaching mathematical modeling and the skills of representation" The 
Roles of Representation in School Mathematics 2001 Yearbook, Ed A A Cuoco and F R Curcio, Reston, VA: National Council of Teachers of Mathematics, 2001, pp 269282.

[25] Moyer P. S., \& Jones M. G., Controlling choice: Teachers, students, and manipulatives in mathematics classrooms, Journal of School Science and Mathematics, vol 1, 2004, pp 104 16.

[26] Borko H., Eisenhart M., Brown C., Underhill R., Jones D., \& Agard P., Learning to teach hard mathematics: Do novice teachers and their instructors give up too easily?, Journal for Research in Mathematics Education, vol 23, 1992, pp 194-222. DOI : 10.2307/749118.

[27] Izsák A., Mathematical knowledge for teaching fraction multiplication, Journal for Cognition and Instruction, vol 26, 2008, pp 95 - 143. DOI : 10.1080/07370000701798529.

[28] Lee S. J, Brown R. E., \& Orrill C. H. Mathematics teachers' reasoning about fractions and decimals using drawn representations, Mathematical Thinking and Learning, vol 13, 2011, pp 198 - 220. DOI : $10.1080 / 10986065.2011 .564993$.

[29] Dienes Z. P., Building up mathematics, London: Hutchinson Educational, 1960.

[30] Sugiyono, "Metode Penelitian Kuantitatif" Kualitatif dan R\&D, Bandung: Afabeta, 2011.

[31] Watanabe T., Representations in teaching and learning fractions, Teaching Children Mathematics, vol 8, 2002, pp 457 - 463.

[32] Van de Walle J., Karp K. S., \& Bay-Williams J. M., Elementary and middle school mathematics: Teaching developmentally, NJ: Pearson, 2013.

[33] Suyono \& Hariyanto, Belajar dan Pembelajaran: Teori dan Konsep Dasar, Bandung: Remaja Rosdakarya, 2014.

[34] Clements M. A., \& Lean G. A., Continuous fraction concepts and cognitive structure, Mathematics Education Research Journal, vol 6, 1994, pp $70-78$.

[35] Zhang X., Clements M. A., \& Ellerton N. F., Conceptual mis(understandings) of fractions: From area models to multiple embodiments,
Mathematics Education Research Journal, vol 27,2015 , pp 233 - 261. DOI : 10.1007/s13394014-0133-8

[36] Woleck, K. R., "Listen to their pictures; An investigation of children's mathematical drawings" The Roles of Representation in School Mathematics, Eds., A. A. Cuoco \& F. R. Curcio, Reston, VA: National Council of Teachers of Mathematics, 2001, pp. 215-227

[37] Van de Walle J., Karp K. S., \& Bay-Williams J. M., Elementary and middle school mathematics: Teaching developmentally, $\mathrm{NJ}$ : Pearson, 2013.

[38] Cramer K., \& Henry A., Using manipulative models to build number sense for addition of fractions Making sense of fractions, ratios, and proportions, Ed., B Litwiller and G Bright , Reston, VA: National Council of Teachers of Mathematics, 2002, pp 41-48.

[39] Petit M., Laird R. E., \& Marsden E. L. A focus on fractions: Bringing research to the classroom, New York: Taylor \& Francis, 2010.

[40] Siebert D \& Gaskin N, Creating, naming, and justifying fractions, Journal Teaching Children Mathematics, vol 12, 2006, pp $394-400$.

[41] Hodges T E, Cady J., \& Collins R. L., Fraction representation: The not-so-common denominator among textbooks, Mathematics Teaching in the Middle School, vol 14, 2008, pp $78-84$.

[42] Cramer K., Wyberg T, \& Leavitt, S. The role of representations in fraction addition and subtraction, Mathematics Teaching in the Middle School, vol 13, 2008, pp 490 - 496.

[43] Martin T., \& Schwartz D. L., Physically distributed learning: adapting and reinterpreting physical environments in the development of fraction concepts, Cognitive Science, vol 29, 2005, pp 587 - 625. DOI: 10.1207/s15516709cog0000_15.

[44] Siegler R. S, Thompson C. A. \& Schneider M. An integrated theory of whole number and fractions development, Cognitive Psychology, vol 62, 2011, pp 273 - 296. DOI: 10.1016/j.cogpsych.2011.03.001

[45] Wu H. H., Understanding numbers in elementary school mathematics, Rhode Island 
: American Mathematical Society, vol 79, 2011.

[46] Behr M.J., Wachsmuth I. \& Post T., Rational number learning aids: Transfer from continuous models to discrete models, Focus on Learning Problems in Mathematics, vol 10, 1988, pp $1-17$.

[47] Behr M. J. \& Post T. R., "Teaching rational number and decimal concepts" :Teaching mathematics in grades K-8: Research-based methods (2nd ed.), Ed. T. R. Post, Boston: Allyn and Bacon, 1992, pp $201-248$.

[48] Charles K. \& Nason R., Young children's partitioning strategies, Educational Studies in Mathematics, vol 43, 2000, pp 191 - 221. DOI : 10.1023/A:1017513716026

[49] Mack N. K., Confounding whole-number and fraction concepts when building on informal knowledge. , Journal for Research in Mathematics Education, vol 26, 1995, pp 422 - 441. DOI : $10.2307 / 749431$ 